\title{
Parallel and Overlapping Proceedings in International Economic Law: Towards an Ordered Co-existence
}

\section{Laurence Boisson de Chazournes"}

\section{Introduction: The Backdrop}

The proliferation of courts and tribunals at the international level brings diversity to international dispute settlement. This multiplicity gives rise to an increasing number of parallel and competing proceedings. Given the relatively recent vintage of this multiplicity of courts and tribunals, such parallel proceedings have, until recently, been rare. As such, international courts and tribunals have had little need to resort to procedural tools for coordinating jurisdiction and, in contrast to domestic legal systems, there had been a paucity of practice amongst international judicial actors having recourse to such tools. Moreover, no real emphasis had been placed on the importance of the role that appropriate procedural rules play in coordinating international jurisdiction. That is, however, beginning to change and this change has been prompted by the problems caused by uncoordinated dispute settlement.

There are a number of undesirable consequences that arise from uncoordinated dispute settlement, including, but not limited to, abusive forum shopping, wasted resources, uncertainty, and conflicting judgments. ${ }^{1}$ The latter can occur when different tribunals make different decisions on disputes with the same facts. The cases of Lauder ${ }^{2}$ and CME v. Czech Republic ${ }^{3}$ are an example of conflicting decisions in the area of investment arbitra-

* Professor of International Law and International Organization at the University of Geneva.

1 See for example M. Waibel, Coordinating Adjudication Processes, in Z. Douglas et al. (eds), The Foundations of International Investment Law: Bringing Theory into Practice (2014), 499, 530.

2 Ronald S. Lauder v. The Czech Republic, UNCITRAL Award 2001, Final Award of 03 September 2001.

3 CME Czech Republic B.V. (The Netherlands) v. The Czech Republic, UNCITRAL Award 2001, Partial Award of 13 September 2001; CME Czech Republic B.V. (The Netherlands) v. The Czech Republic, UNCITRAL Award 2003, Final Award of 14 March 2003. 
tion. Another often-mentioned example of discrepancy is the interpretation of necessity as a circumstance precluding wrongfulness by the CMS $v$. Argentina ${ }^{4}$ and $L G \& E v$. Argentina ${ }^{5}$ tribunals.

Conflicting judgments may be the result of parallel proceedings or overlapping proceedings. Parallel proceedings can involve the same parties in different courts that never connect with each other while overlapping proceedings involve the connections that two disputes may have with each other on the material level of the applicable rules. Parallel proceedings may exist between an investor and a host State when the former is being sued by the latter before national courts for tax violations, for example. This does not deprive the investor of the possibility to bring a claim under an applicable treaty before an international tribunal. Overlapping procedures, on the other hand, may occur when a measure impacts one or more regimes at the same time, such as trade and investment.

To avoid these kinds of situations, conflicting judgments more generally and undermining the rule of law, coordination among international courts and tribunals becomes essential. To this end, procedural rules play an increasingly important role. Some are borrowed from domestic legal systems. ${ }^{6}$ That being said, it is important to emphasize that they are being adapted and not imported wholesale into international law. The adaptation of such mechanisms is made by both international courts and tribunals themselves and, occasionally, states acting as legislators.

The traditional toolkit for dealing with conflicting judgments includes such procedural mechanisms as lis pendens, fork in the road provisions, connexité and comity. ${ }^{7}$ While these all essentially lead to the same result in theory (one tribunal declining jurisdiction in favour of another), they each offer quite different means of getting to that result. International economic law (in particular investment and trade regimes) offers interesting perspectives for the contemporary operation of these mechanisms. As a matter

4 CMS Gas Transmission Company v. The Republic of Argentina, ICSID Case No. ARB/01/8, Award of 12 May 2005.

5 LG\&E Energy Corp. v. The Republic of Argentina, ICSID Case No. ARB/02/1, Decision on Liability of 03 October 2006. See S. Schill, International Investment Law and the Host State's Power to Handle Economic Crises - Comment on the ICSID Decision in LG\&E v. Argentina, 24(3) Journal of International Arbitration (2007), 265-286.

6 As in other areas, H. Lauterpacht, Private Law Sources and Analogies of International Law (1927), viii.

7 In this article, res judicata, which can also be characterized as a tool for declining jurisdiction, will not be considered as it applies to successive rather than parallel proceedings. 
of fact, it is in this particular area of international law that the judiciary, and states, have become aware of the importance of these tools for resolving the problems of conflicting and parallel proceedings.

In this article, I will consider how these tools are being adapted for a use at the international level and chart some of the new trends that reveal a more systemic approach in this respect. These new trends are the result of a realisation amongst international courts, tribunals, and state actors that action needs to be taken to coordinate this increasingly complex world of dispute settlement. As a result, we can see an increasing public character of international procedural rules, in the sense that they are enshrined and codified in international agreements and instruments.

\section{Lis Pendens and Forum Non Conveniens in their Traditional Forms}

Let us first consider the concept of lis pendens in its classical understanding. Under civil law, in contrast to the approach of common law, the principle of lis pendens has traditionally been applied by courts faced with a conflict of jurisdiction. Civil law will not have a response until there is an actual conflict that is, until the same case comes before two different courts. ${ }^{8}$ Once there is an actual conflict, the principle is applied subject to the so-called triple identity test, namely that the cause of action, the parties and the object of the dispute are the same. That being the case, a second court cannot hear the proceedings, if the same action is already pending before a court in another country. Under the civil law approach, lis pendens ensures that a standard procedure is followed in each instance and respects the procedure taking place in another jurisdiction. Notwithstanding, the lis pendens doctrine is intended to serve the public purpose of avoiding a dispute between two courts on which one should hear the case.

An alternative approach for declining jurisdiction is found in the common law doctrine of forum non conveniens. ${ }^{9}$ This tool is applied by a court or tribunal where they consider that another court or tribunal seized of the matter is more appropriately positioned to decide the dispute. This doctrine attempts to consider which court is the most appropriate and it is of little importance which was first seized. This approach, in contrast with lis

8 T. Hartley, The Modern Approach to Private International Law: International Litigation and Transactions from a Common Law Perspective, 319 Collected Courses of the Hague Academy of International Law (2006), 142.

9 Ibid. 
pendens, is discretionary. Whilst this may often be a more rational approach than lis pendens, its disadvantage is that it allows more scope for subjectivity and is less certain. The doctrine also differs in that it does not wait until a lis pendens situation has actually arisen. It operates not only when the case is pending before the courts of another country, but also when it could have been brought before them. It applies even if there is no conflict of jurisdiction. Concerned not only with resolving a conflict of jurisdiction-a public purpose in the way that it coordinates proceedings-but also with doing justice to the parties by ensuring that the most appropriate court hears the case. The latter is the main objective. It constitutes, in this way, an example of the common law giving greater weight to private interests than to public interests because it is more concerned with doing justice in the individual case than with the strict application of a mechanism by which jurisdiction is automatically declined; overall, providing greater certainty. ${ }^{10}$ The discretionary nature and margin of appreciation given to courts is notable and these latter elements are reflected in the approaches developed at the international level for declining jurisdiction, as we will see in further details below.

In devising the private international law regime of the European Union, the approach of the civil law was chosen over that of the alternative common law approach. Lis pendens is laid down in Article 29 of the Brussels I Regulation (Recast 2012) ${ }^{11}$ (formerly Article 27), which courts of European Union Member States must apply when faced with multi-jurisdictional cases involving other EU Member States. Article 29 provides:

10 A clear articulation of the forum non conveniens doctrine is provided by the English case of Spiliada Maritime Corporation v. Cansulex [1987] AC 460. In that case, Lord Goff noted that the defendant must show that another forum is available that is clearly or distinctly more appropriate than the English forum. That court must be in a country that has the most 'real and substantial connection' and in making this assessment connecting factors such as governing law and the place where the parties reside or carry on business, in addition to factors more directly related to convenience, such as where the evidence is available, must all be examined. Moreover, Lord Goff reasoned that advantages to the plaintiff are no longer relevant. There must be special circumstances by reason of which justice requires that the trial should nevertheless take place in England (e.g. that he would not obtain a fair trial due to racial or political bias). While it is not too difficult to weigh up the normal connecting factors but it is more difficult to determine which special circumstances will be taken into account.

11 Regulation (EU) No 1215/2012 of the European Parliament and of the Council of 12 December 2012 on Jurisdiction and the Recognition and Enforcement of Judgments in Civil and Commercial Matters (Recast), OJ L 351/1. 
Where proceedings involving the same cause of action and between the same parties are brought in the courts of different member states, any court other than the court first seized must of its motion stay its proceedings until such time as the jurisdiction of the first seized court is established. Once this occurs, it must decline jurisdiction in favour of that court.

This first-in-time approach has been criticized as being overly rigid and allowing what has been called "Italian torpedo" situations in which parties seeking to delay the outcome of a dispute commence proceedings in a jurisdiction where court proceedings are typically slow moving. ${ }^{12}$ Owing to the exclusive jurisdiction provision, all other courts in other Member States must then stay proceedings until the court first seized of the matter determines whether it has jurisdiction, even if there is a choice of court agreement in place. These criticisms appear to have been taken on board by the European Commission and the Brussels I Regulation has recently been recast to avoid abusive use of the lis pendens rule in cases where a choice of court agreement is in place. ${ }^{13}$ In particular, it seeks to avoid Italian torpedo situations by allowing an EU Member State court to proceed with hearing a case where the former is the subject of an exclusive jurisdiction clause, even if a case has been filed in another Member State court before.

Further still, Articles 33 and 34 of the Brussels I Regulation extend lis pendens to parallel and related proceedings in third States. As such, where proceedings in the court of an EU Member State are pending before the courts of non-EU Member State and those proceedings are based on the same cause of action or are between the same parties, the EU Member State court may stay the proceedings before it. However, this is only the case where the EU Member State court expects that the judgment of the nonEU Member State court will be capable of recognition or enforcement in the relevant EU Member State and the court considers it necessary for the proper administration of justice. Similarly, where there is a related action

12 See for example J. Wood \& N. Allan, Sinking the Italian torpedo: the recast Brussels Regulation, International Law Office (19 February 2015), available at http://w ww.internationallawoffice.com/Newsletters/Litigation/European-Union/RPC/Sin king-the-Italian-torpedo-the-recast-Brussels-Regulation (last visited 6 December 2018).

13 See S. Garvey, Brussels Regulation (Recast): Are You Ready?, Allen \& Overy Publication (18 March 2015), available at http://www.allenovery.com/publications/en-g b/Pages/BRUSSELS-REGULATION-(RECAST)-ARE-YOU-READY.aspx (last visited 6 December 2018). 
pending before a non-EU Member State court, an EU Member State court may stay the proceedings before it if it considers it expedient to hear the related actions together. This is on the condition that it expects the non-EU Member State court to deliver a judgment capable of recognition and enforcement in a third state; and the EU Member State court sees it as necessary for the proper administration of justice. These provisions are particularly significant for the way in which they show utmost concern for the coordination of proceedings. They suggest that lis pendens may be considered as a rule of international public order and not necessarily reliant on reciprocity for its operation. ${ }^{14}$

As is evident from the text of the above provision in Article 29, there are a number of key elements to the lis pendens principle as expressed in the Brussels I Regulation. These elements include the same cause of action and the same parties. The various elements of the lis pendens doctrine have been addressed by the Court of Justice of the European Union (CJEU). As for the same cause of action, in Gubisch Maschinenfabrik v. Palumbo, ${ }^{15}$ the CJEU gave a fairly wide meaning to the idea of the same cause of action in proceedings taking place in both Germany and Italy. The proceedings were commenced in Germany by a German manufacturer to recover the price of machinery that had been ordered by an Italian resident. Afterwards, proceedings were commenced in Italy by Palumbo in an effort to obtain a declaration that the contract was inoperative as the original order had been revoked. In the context of this case, the purpose of the German action was to give effect to a contract and that of the Italian action was to deprive it of effect. If the case would have been allowed to continue they clearly could have resulted in irreconcilable judgments. The CJEU held that the underlying cases involved the same cause of action and the Italian court had to give up jurisdiction.

As to the same parties, a more restrictive approach seems to have been adopted. For example, in the Maciej Rataj (The Tatry) case, ${ }^{16}$ the CJEU reasoned that where some but not all of the parties to the second action are the same as the parties to the first action, the lis pendens rule applies only to the extent to which the parties are the same.

14 This is a point argued for by Campbell McLachlan, see C. McLachlan, Lis Pendens in International Litigation, 336 Collected Courses of the Hague Academy of International Law (2009).

15 Gubisch Maschinenfabrik v. Palumbo, Case 144/86, Judgment of 08 December 1987, [1987] ECR 4861.

16 Maciej Rataj (The Tatry), Case 406/92, Judgment of 06 December 1994, [1994] ECR I-5439. 
Beyond the European context, it has been stated that " $[t]$ he widespread use and similarity of the concept of lis pendens in the national procedural laws of States of all legal traditions as well as its inclusion in a number of bi- and multilateral agreements is evidence that lis pendens can be regarded as a general principle of law in the sense of Article 38 of the ICJ Statute".17 That said, it is pertinent to note that the transferability of lis pendens at the international level has yet to be thoroughly tested. Notwithstanding, we will now turn to consider its application by international courts and tribunals, as well as its occurrence in international treaties.

\section{Contemporary Application of Lis Pendens at the International Level}

In the past, instances of the application of the lis pendens principle at the international level have been sporadic, showing a reluctance of courts and tribunals to accept the applicability of the lis pendens principle and injecting a measure of unpredictability in its operation. For example, in the Certain German Interests in Polish Upper Silesia case, the Permanent Court of Justice took into consideration the principle of lis pendens, but ultimately concluded that its requirements had not been met in that case. ${ }^{18}$ Similarly, in Benvenuti and Bonfant $v$. Congo, an investment tribunal considered that lis pendens might be applicable but concluded that certain requirements of the principle were not met. ${ }^{19}$ In $S G S v$. Pakistan, the Tribunal also considered and dismissed the applicability of lis pendens. ${ }^{20}$ Within the international legal order, this is explained by the fact that State consent to adjudication cannot be presumed. Moreover, in respect of international arbitration, the existence of an agreement providing for exclusive jurisdiction

17 A. Reinisch, The Use and Limits of Res Judicata and Lis Pendens As Procedural Tools to Avoid Conflicting Dispute Settlement Outcomes, 2 The Law and Practice of International Courts and Tribunals (2004), 37, 48. Though there are some who are sceptical of this status, see $\mathrm{H}$. Wehland, The Coordination of Multiple Proceedings in Investment Treaty Arbitration (2013), 129.

18 Certain German interests in Polish Upper Silesia (Germany v. Poland), Judgment, PCIJ Series A no 7 ICGJ 241 (1926).

19 S.A.R.L. Benvenuti and Bonfant v. People's Republic of the Congo, ICSID Case No. ARB/77, Award of 08 August 1980.

20 SGS Société Générale de Surveillance S.A. v. Islamic Republic of Pakistan, ICSID Case No. ARB/01, Decision on Objections to Jurisdiction of 06 August 2003, para 182. 
should normally preclude the exercise of jurisdiction by any other judicial body (either international or domestic). ${ }^{21}$

However, recently some courts and tribunals have shown a willingness to engage with this principle, crafting a broader conception of lis pendens. While the triple identity test for lis pendens may be difficult to meet, ${ }^{22}$ more liberal interpretations have been offered by international tribunals. For example, concepts such as the substantial identity of the parties, piercing the corporate veil, and single economic entity are all ways that could be used to overcome the traditionally strict hurdles. ${ }^{23}$ In an example of such a liberal approach, the ITLOS Tribunal in the Southern Bluefin Tuna case examined the essential basis of the dispute and concluded that the case before it was substantially the same as the one before the Commission for the Conservation of Southern Bluefin Tuna (CCSBT). ${ }^{24}$ This was in spite of the fact that there were differing legal bases in the two disputes. That being said, the Tribunal decided the case on the basis of another provision of the Law of the Sea Convention. In fact, the approach of the Tribunal in this case has been characterized as laissez-faire in the way it treated each obligation implicated in the case as distinct. ${ }^{25}$ Commentators have warned that such an approach could actually lead to more parallel proceedings of a complex nature with different tribunals deciding upon different obligations pertaining to the same dispute. ${ }^{26}$ Another example is provided by SPP $v$. Egypt, in which an ICSID tribunal suspended litigation while there was a parallel proceeding between the same parties at the Cour de Cassation in France on whether the parties had agreed to submit the dispute to arbitration. ${ }^{27}$ While the issue before the Cour de Cassation was not strictly the

21 G. Kaufmann-Kohler et al., Consolidation of Proceedings in Investment Arbitration: How Can Multiple Proceedings Arising from the Same or Related Situations be Handled Efficiently? Final Report on the Geneva Colloquium Held on 22 April 2006, 21(1) ICSID Review: Foreign Investment Law Journal (2006), 59.

22 See for example CME Czech Republic B.V. (The Netherlands) v. The Czech Republic, supra note 3. See also A. Reinisch, The Issues Raised by Parallel Proceedings and Possible Solutions, in M. Waibel (ed.), The Backlash Against Investment Arbitration: Perceptions and Reality (2010), 122 (arguing that the triple-identity test ought to be relaxed in certain circumstances).

23 Ibid., 123.

24 Southern Bluefin Tuna Case (Australia and New Zealand v. Japan), 39 ILM 1359, Award on Jurisdiction and Admissibility, Decision of 4 August 2000, paras. 52, 59.

25 McLachlan, supra note 14.

26 Ibid.

27 Southern Pacific Properties (Middle East) Limited v. Arab Republic of Egypt, ICSID Case No. ARB/84/3, Decision on Jurisdiction I, 27 November 1985, 3 ICSID Reports 112. 
same as that before the arbitral tribunal, the latter tribunal nevertheless viewed that it was "in the interest of international judicial order" to stay the proceedings before it "pending a decision by the other tribunal". 28

In addition to this more flexible and liberal application of lis pendens by the international judiciary, we may also observe the way in which new treaties are developing, adapting and expanding manifestations of the principle. Under the Comprehensive Economic and Trade Agreement between Canada and the EU (CETA), ${ }^{29}$ for example, a choice of forum clause and restriction on litigating an obligation which is equivalent in substance in two fora is present in Article 29.3.1-2. These sub-paragraphs provide:

1. Recourse to the dispute settlement provisions of this Chapter is without prejudice to recourse to dispute settlement under the WTO Agreement or under any other agreement to which the Parties are party.

2. Notwithstanding paragraph 1 , if an obligation is equivalent in substance under this Agreement and under the WTO Agreement, or under any other agreement to which the Parties are party, a Party may not seek redress for the breach of such an obligation in the two fora. In such case, once a dispute settlement proceeding has been initiated under one agreement, the Party shall not bring a claim seeking redress for the breach of the substantially equivalent obligation under the other agreement, unless the forum selected fails, for procedural or jurisdictional reasons, other than termination under paragraph 20 of Annex 29-A, to make findings on that claim.

Referring in Article 29.3.2 to a substantially equivalent obligation, the parties to this treaty have thereby used a broad formula in order to incorporate a comprehensive form of safeguard against lis pendens, rather than a classical interpretation based on the identical nature of claims and obligations; as such, an attempt has been made to prevent parallel procedures as much as possible. A similar provision is contained in Article 24 of the EU-Vietnam Free Trade Agreement, ${ }^{30}$ which reads, in its relevant part, as follows:

28 Ibid., 129.

29 Comprehensive Economic and Trade Agreement between Canada and the European Union [CETA], not yet in force at time of writing. Provisional application from 21 September 2017. Consolidated text available at http://trade.ec.europa.eu/ doclib/docs/2014/september/tradoc_152806.pdf (last visited 6 December 2018).

30 Free Trade Agreement between the European Union and the Socialist Republic of Vietnam, not yet in force at time of writing. Text available at http://trade.ec.europ a.eu/doclib/press/index.cfm?id=1437 (last visited 6 December 2018). 
1. Recourse to the dispute settlement provisions of this Chapter shall be without prejudice to any action in the WTO framework, including dispute settlement action, or in any other international agreement to which both Parties are parties.

2. By way of derogation from paragraph 1 , a Party shall not, for a particular measure, seek redress for the breach of a substantially equivalent obligation under this Agreement and under the WTO Agreement or in any other international agreement to which both Parties are parties in the relevant fora. Once a dispute settlement proceeding has been initiated, the Party shall not bring a claim seeking redress for the breach of the substantially equivalent obligation under the other agreement to the other forum, unless the forum selected first fails for procedural or jurisdictional reasons to make findings on the claim seeking redress of that obligation. [...]

The inclusion of these lis pendens-type devices is an interesting contribution to avoiding conflicts of jurisdiction in modern free trade agreements (FTAs). ${ }^{31}$

\section{Connexité, Related Actions and Consolidation in a Contemporary Context}

Connexité and variations of this concept, such as related actions, are emerging as a further way in which to coordinate jurisdiction and avoid parallel and overlapping proceedings in international litigation. Connexité is a concept of French law that regulates a conflict of jurisdiction where two cases are pending which are not identical (so lis pendens does not apply) but are similar enough that they should be consolidated into one case. ${ }^{32}$ This doctrine is discretionary in nature and so it would appear to be a close cousin of forum non conveniens. It is also less strict insofar as it does not require identical elements in the concerned cases. There is, for example, no requirement that the parties be the same in connected disputes. The discretion to connect proceedings may be exercised where it is expedient to do so and where there is a risk that two judgments may be irreconcilable. ${ }^{33}$

31 See P.-J. Kuijper, TDM Special Issue on the Comprehensive Economic and Trade Agreement between the European Union and Canada (CETA), TDM (2016), available at https://www.transnational-dispute-management.com/article.asp?key=2309 (last visited 6 December 2018).

32 H. Black, A Dictionary of Law (1991), 253.

33 G. Kaufmann-Kohler et al., supra note 21. 
Related actions are also provided for under the Brussels I Regulation (Recast), referred to earlier. Article 30 (formerly Article 28) states that "where related actions are pending in the courts of different Member States, any court other than the court first seized may stay its proceedings". Furthermore, Article 30(2) provides that the subsequent court may even decline jurisdiction rather than simply stay proceedings.

With the proliferation of trade and investment agreements, it is increasingly likely that connected claims will arise around related issues and the potential therefore exists for these claims to be connected or heard together. Given the recent trends concerning other procedural tools designed to coordinate jurisdiction, it is foreseeable that tribunals pursue such an approach whereby similar claims and issues are connected.

It is helpful to illustrate the potential for connecting claims with several possible scenarios. One situation could be an umbrella clause combined with a broad compromissory clause ("any dispute relating to investment") which is connected to trade related claims. Another could involve a mostfavoured nation (MFN) clause in a BIT that may apply both to benefits granted in other BITs as well as in other investment-related treaties such as the General Agreement on Trade in Services (GATS), the Agreement on Trade-Related Aspects of Intellectual Property Rights (TRIPS) or FTAs. In accordance with the MFN obligation included in the GATS, the parties are committed to treating services and service providers in a no less favourable way than like services and service providers from any other country. We might ask whether an MFN clause in a BIT extends to benefits granted to other countries in the WTO or an FTA? Conversely, does the MFN provision in GATS or an FTA automatically incorporate substantive or dispute settlement advantages given to another country in a BIT?

More generally, the approach of connecting related issues has begun to feature in certain international instruments. This has been characterized as consolidation and is envisaged as joining two or more pending arbitrations into one proceeding. One of the best examples is Article 1126 of the North American Free Trade Agreement (NAFTA), ${ }^{34}$ which also provides for the establishment of a special consolidation tribunal to decide on the consolidation of relevant arbitrations under NAFTA's Chapter 11. The consolidation tribunal has the discretion to decide whether it consolidates claims en-

34 North American Free Trade Agreement, in force as of 1 January 1994. Available at https://www.nafta-sec-alena.org/Home/Texts-of-the-Agreement/North-American-F ree-Trade-Agreement?mvid=2 (last visited 6 December 2018). 
tirely or partially. Consolidation under NAFTA Article 1126 can be undertaken even without the explicit consent of the parties.

Article 10 of the International Chamber of Commerce (ICC) Rules provides for the consolidation of arbitrations, although it does not make provision for a consolidation tribunal as is the case under NAFTA. Article 10 stipulates:

The Court may, at the request of a party, consolidate two or more arbitrations pending under the Rules into a single arbitration, where:

a) the parties have agreed to consolidation; or

b) all of the claims in the arbitrations are made under the same arbitration agreement; or

c) where the claims in the arbitrations are made under more than one arbitration agreement, the arbitrations are between the same parties, the disputes in the arbitrations arise in connection with the same legal relationship, and the Court finds the arbitration agreements to be compatible.

In deciding whether to consolidate, the Court may take into account any circumstances it considers to be relevant, including whether one or more arbitrators have been confirmed or appointed in more than one of the arbitrations and, if so, whether the same or different persons have been confirmed or appointed.

When arbitrations are consolidated, they shall be consolidated into the arbitration that commenced first, unless otherwise agreed by all parties.

A number of recent trade and investment agreements appear to have followed the approach in NAFTA and the ICC Rules insofar as they also make provision for the consolidation of proceedings. These are interesting in the way that, through the vehicle of consolidation, they adopt a broader notion of connexité. Article 8.43 (1) of CETA provides for consolidation thus:

1. When two or more claims that have been submitted separately pursuant to Article 8.23 have a question of law or fact in common and arise out of the same events or circumstances, a disputing party or the disputing parties, jointly, may seek the establishment of a separate division of the Tribunal pursuant to this Article and request that such division issue a consolidation order (request for consolidation). 
Article 9.28 of the Trans-Pacific Partnership (TPP) ${ }^{35}$ and Article 27(1) of the Transatlantic Trade and Investment Partnership (TTIP) ${ }^{36}$ proposal also make provision for consolidation in similar language. However, while all these provisions appear to follow NAFTA's lead in consolidating similar or related proceedings, there remains a difference. Under NAFTA, the tribunal may consolidate proceedings without the consent of the parties whereas under the ICC Rules, CETA, TPP and TTIP proposal, consolidation must be at the request of the disputing parties.

That said, Article 27(3) of TTIP goes on to set out the circumstances in which a formal consolidation mechanism, not dissimilar to that under NAFTA, may come into effect where the disputing parties disagree on the consolidation of proceedings:

In the event that the disputing parties referred to in paragraph 2 have not reached an agreement on consolidation within thirty days of the receipt of the request for consolidation referred to in paragraph 1 by the last claimant to receive it, the President of the Tribunal shall constitute a consolidating division of the Tribunal pursuant to Article 9. The consolidating division shall assume jurisdiction over all or part of the claims, if, after considering the views of the disputing parties, it decides that to do so would best serve the interest of fair and efficient resolution of the claims, including the interest of consistency of awards.

This represents an endorsement of the concept of connexité and entrusts to a tribunal the discretionary power of consolidation, to be exercised on the basis of fairness, efficiency and the consistency of decisions. It is the strongest evidence yet that connexité is gaining ground.

35 Trans-Pacific Partnership (TPP), not yet in force at time of writing. Available at https://ustr.gov/trade-agreements/free-trade-agreements/trans-pacific-partnership/t pp-full-text (last visited 6 December 2018).

36 Transatlantic Trade and Investment Partnership [TTIP], Text of the European Commission's Proposal for Chapter II - Investment, not yet in force at time of writing. Available at http://trade.ec.europa.eu/doclib/docs/2015/september/tradoc _153807.pdf (last visited 6 December 2018). 
Another procedural option is available in Article 8.24 of CETA, which provides:

Where a claim is brought pursuant to this Section and another international agreement and:

(a) there is a potential for overlapping compensation; or

(b) the other international claim could have a significant impact on the resolution of the claim brought pursuant to this Section, the Tribunal shall, as soon as possible after hearing the disputing parties, stay its proceedings or otherwise ensure that proceedings brought pursuant to another international agreement are taken into account in its decision, order or award.

This formulation offers something akin to connexité without consolidation insofar as the tribunal should take into account parallel proceedings in its own decision or a form of lis pendens where it may stay proceedings. It represents yet another way in which connexité is being conceived differently for dispute settlement at the international level.

As these examples demonstrate, the tools for coordinating jurisdiction are being crafted both by international tribunals and in new trade and investment agreements. In these new tools we see both traditional non-discretionary elements, such as the mechanical operation of lis pendens, but also newly conceived discretionary elements, such as connexité and consolidation mechanisms. However, they are not the only tools that are being developed for coordinating jurisdiction in the field of international economic law.

\section{Fork in the Road, Election and Waiver Provisions: Their Progressive Acceptance and Evolution}

Fork in the road clauses are another way in which one court or tribunal may be deprived of jurisdiction over another competent court or tribunal. Fork in the road provisions leave it to the party to decide which forum is most appropriate, although this may also be dictated by the legal nature of a particular claim or the applicable law. ${ }^{37}$ These types of clauses will be considered first in the investment law field and then in the trade law field.

37 McLachlan, supra note 14 . 


\section{A. Investment Law}

A fork in the road clause is a provision in many BITs that provides for a choice between local remedies in domestic courts and international arbitration. Once one means has been chosen for the resolution of a given dispute, the other means cannot be resorted to. However, this is subject to the proviso that the legal nature of the claim before a domestic court is indistinct from the legal nature of the claim before an international tribunal. As such, if one claim is essentially based on a contract and the other essentially based on a treaty, the two sets of proceedings would likely be allowed to proceed concurrently. This was the case in Genin v. Estonia where, despite the Respondent state arguing otherwise, the arbitral tribunal held that the fact the Claimant had pursued proceedings in Estonian courts did not preclude him from having recourse to investment arbitration. The Tribunal reasoned that the claims and causes of action before the Estonian courts and the arbitral tribunal were different. ${ }^{38}$ It would appear that in many cases involving fork in the road provisions, arbitral tribunals have found similar differences between the proceedings at issue..$^{39}$ In other cases, fork in the road clauses have been said to enhance certainty, as was spelled out in Maffezini v. Spain:

[...] if the parties have agreed to a dispute settlement arrangement which includes the so-called fork in the road, that is, a choice between submission to domestic courts or to international arbitration, and where the choice once made becomes final and irreversible, this stipulation cannot be bypassed by invoking the [MFN] clause. This conclusion is compelled by the consideration that it would upset the finality of arrangements that many countries deem important as a matter of public policy. 40

Parties have inserted fork in the road clauses in treaties as a means for coordinating national and international jurisdiction over disputes arising directly or indirectly from the treaty. There are many examples of such provi-

38 Alex Genin, Eastern Credit Limited, Inc. And A.S. Baltoil v. The Republic of Estonia, ICSID Case No. ARB/99/2, Award of 25 June 2001, 17 ICSID Rev (2002), 79-81.

39 C. Schreuer, Travelling the BIT Route: Of Waiting Periods, Umbrella Clauses and Forks in the Road, 5(2) Journal of World Investment and Trade (2004), 231; C McLachlan, Lis Pendens in International Litigation (2009).

40 Emilio Augustin Maffezini v. The Kingdom of Spain, ICSID Case No. ARB/97/7, Decision on Jurisdiction of 25 January 2000, 16 ICSID Rev (2001), 203. 
sions in investment treaties and Article 10(2) of the BIT between Greece and Albania is typical of the underlying idea. It provides that if disputes cannot be settled amicably, "the investor or the Contracting Party concerned may submit the dispute either to the competent court of the Contracting Party or to an international arbitration tribunal [...]". Variations of the fork in the road clause are also present in multilateral conventions, as we will see shortly.

In the past, many investment treaties simply required that domestic remedies be exhausted before international proceedings were commenced. ${ }^{41}$ Variations on the fork in the road clause, while they are invariably less strict, also exist. For example, BITs may set a time limit for domestic courts to resolve an issue before they exercise jurisdiction, ${ }^{42}$ and some BITs only allow international arbitration to proceed if there has not been a first instance decision by the courts of the host State. ${ }^{43}$

In all events, the relatively simple criterion, which triggers the operation of a fork in the road clause, is the identical nature of the dispute and parties in both juridical proceedings. Despite its apparent simplicity, these can nevertheless be difficult criteria to apply in practice, given that both private and public parties may be involved in litigation at the domestic level in different capacities. Tribunals have often taken a relatively strict approach in their application of the criteria. In Enron v. Argentina, the Respondent had objected to the arbitral tribunal's jurisdiction on the basis of the fork in the road provision under the Argentina-US BIT, claiming that Enron had been embroiled in litigation before courts in Argentina seeking relief for tax measures that were the subject of the dispute before the arbitral tribunal. The Tribunal held:

This Tribunal is mindful of the various decisions of ICSID Tribunals also discussing this very issue, particularly Compania de Agua del Acon-

41 Schreuer, supra note 39, giving Agreement Between the Government of Ghana and the Government of the Socialist Republic of Romania on the Mutual Promotion and Guarantee of Investments, 14 September 1989, Article 4(3) as an example, available at http://investmentpolicyhub.unctad.org/Download/TreatyFile/145 9 (last visited 6 December 2018).

42 Agreement between the Argentine Republic and the Kingdom of Spain on the Reciprocal Promotion and Protection of Investments, 3 October 1991, 1699 UNTS 188, Article x(3)(a).

43 Agreement Between the Republic of Austria and the Republic of Macedonia on the Promotion and Protection of Investments, 28 March 2001, Article 13(3), available at http://investmentpolicyhub.unctad.org/Download/TreatyFile/3313 (last visited 6 December 2018). 
quija, Genin, and Olguin. In all these cases the difference between the violation of a contract and the violation of a treaty, as well as the different effects that such violations might entail, have been admitted, not ignoring of course that the violation of a legal rule will always have similar negative effects irrespective of its nature. It has accordingly been held that even if there was recourse to local courts for breach of contract this would not prevent resorting to ICSID arbitration for violation of treaty rights, or that in any event, as held in Benvenuti \& Bonfant, any situation of lis pendens would require identity of the parties. Neither will these considerations be repeated here.

The Tribunal notes that in the present case the Claimants have not made submissions before local courts and those made by TGS are separate and distinct. Moreover, the actions by TGS itself have been mainly in the defensive so as to oppose the tax measures imposed, and the decision to do so have been ordered by ENARGAS, the agency entrusted with the regulation of the gas sector. The conditions for the operation of the principle electa una via or fork in the road are thus simply not present. The Tribunal accordingly dismisses the objection to jurisdiction on this other ground. ${ }^{44}$

More recently, several tribunals have applied fork in the road clauses less narrowly, which in turn has meant that most or all of the claims in the respective disputes have been dismissed on jurisdictional grounds. For example, in Pantechniki v. Albania, the sole arbitrator Jan Paulsson preferred to adopt an approach that asked "[...] whether or not 'the fundamental basis of a claim' sought to be brought before the international forum is autonomous of claims to be heard elsewhere". ${ }^{45}$ Latterly, the ICSID tribunal in $H$ \& $H$ Enterprises $v$. The Arab Republic of Egypt applied a similar test based on the fundamental basis of the claim instead of, for example, a more formalistic triple-identity test. ${ }^{46}$ In that case, the claimant had argued that the most favoured nation (MFN) clause in the applicable BIT meant

44 Enron Corp. and Ponderosa Assets LP v. Argentina, ICSID Case No. ARB/01/3, Decision on Jurisdiction of 14 January 2004, paras. 97-98.

45 Pantechniki v. Albania, ICSID Case No. ARB/07/21, Award of 30 July 2009, para. 61.

46 Ibid.; H \& H Enterprises Investment Inc. v. Arab Republic of Egypt, ICSID Case No. ARB/09/15, Decision on Objections to Jurisdiction of 05 June 2012. See J. Dahlquist, in a newly-surfaced ruling, MFN can't be used to bypass a fork-in-theroad clause, and the latter clause defeats most of the investor's claims against Egypt, Investment Arbitration Reporter (2016), available at http://www.iareporter .com/articles/in-newly-surfaced-rulingmfn-cant-be-used-to-bypass-fork-in-the-road- 
they could be entitled to better treatment afforded under an alternative BIT which did not contain a fork in the road clause. The Tribunal, however, disagreed. Instead, it found that dispute settlement provisions were different to substantive provisions and that the MFN clause did not cover the former category of provisions. ${ }^{47}$ Since claims that were fundamentally the same as the present dispute had previously been litigated before another arbitral tribunal and an Egyptian court, the fork in the clause had been triggered..$^{48}$

Waivers may also be considered as fork in the road-type provisions as they aim at the prevention of the same proceedings being filed in different fora. ${ }^{49}$ Waivers provide for the renunciation of a party's rights to a given tribunal. They may be executed voluntarily by parties to litigation or stipulated by a treaty as a precondition to the commencement of litigation. The advantage they offer for the claimant is that the latter may opt to have the case litigated in a local court but still leave open the possibility of investment treaty arbitration later if the investor considers that the treaty standards continue to be violated by the state. Any later investment tribunal would consider the conduct of the host state, including the treatment of the claimant in its domestic courts. The advantage for the host state and for the subsequent investment tribunal is that an investment tribunal does not have to deal with parallel proceedings in the courts of the host state. ${ }^{50}$ An example of a waiver provision is Article 1121(1) of NAFTA, which states that:

A disputing investor may submit a claim under Article 1116 to arbitration only if:

(a) the investor consents to arbitration in accordance with the procedures set out in this Agreement; and

(b) the investor and, where the claim is for loss or damage to an interest in an enterprise of another Party that is a juridical person that the investor owns or controls directly or indirectly, the enterprise, waive their right to initiate or continue before any administrative tribunal or court under the law of any Party, or other dispute settlement procedures, any proceedings with respect to the measure of the disputing

and-latter-clause-defeats-most-of-investors-claims-against-egypt/ (last visited 6 December 2018).

47 Ibid.

48 Ibid.

49 Kaufmann-Kohler et al., supra note 21.

50 McLachlan, supra note $14,397$. 
Party that is alleged to be a breach referred to in Article 1116, except for proceedings for injunctive, declaratory or other extraordinary relief, not involving the payment of damages, before an administrative tribunal or court under the law of the disputing Party.

Similarly, under NAFTA's Article 1120, the investor must choose between NAFTA and UNCITRAL arbitration, and Article 1121(2)(b) of NAFTA then provides that the investor must:

waive their right to initiate or continue before any administrative tribunal or court under the law of any Party, or other dispute settlement procedures, any proceedings with respect to the measure of the disputing Party that is alleged to be a breach referred to in Article 1117, except for proceedings for injunctive, declaratory or other extraordinary relief, not involving the payment of damages, before an administrative tribunal or court under the law of the disputing Party.

In Waste Management I, an ICSID tribunal concerned itself with this provision and held that the Claimant was obliged "[...] in accordance with the waiver tendered, to abstain from initiating or continuing any proceedings before other courts or tribunals with respect to those measures pleaded as constituting a breach of the provisions of NAFTA", and that the purpose of Article 1121 was to prevent "[...] the imminent risk that the Claimant may obtain the double benefit in its claim for damages" ${ }^{11}$ As is becoming evident, through both fork in the road clauses and waivers, we can see efforts being made by both legislative and judicial actors to answer concerns around the duplication of proceedings and double recovery in particular.

Interestingly, newly adopted treaties, such as CETA, have gone a step further. Article 8.22 on "Procedural and other requirements for the submission of a claim to the Tribunal" reads as follows:

An investor may only submit a claim pursuant to Article 8.23 if the investor: $[\ldots]$ (f) withdraws or discontinues any existing proceeding before a tribunal or court under domestic or international law with respect to a measure alleged to constitute a breach referred to in its claim; and (g) waives its right to initiate any claim or proceeding before a tribunal or court under domestic or international law with respect to a measure alleged to constitute a breach referred to in its claim.

51 Waste Management, Inc. v. United Mexican States, ICSID Case No. $\operatorname{ARB}(\mathrm{AF}) / 98 / 2$, Award and Dissenting Opinion of 2 June 2000 and 8 May 2000. 
This approach differs from the classically conceived fork in the road provision that leaves the choice of forum to the claimant. Instead, here, the CETA specifically requires that the investor provides evidence that they have discontinued any other proceedings and that they waive their right for any further proceedings. By requiring the claimant to provide evidence that there is no overlapping or parallel proceedings, the CETA adopts an even stronger approach to mitigate the risk of conflicting jurisdiction. It will thus be interesting to see how the distinction between contract claims and treaty claims might be addressed under this scenario.

The approach pursued in the EU's proposal for the TTIP chapter on investment does not contain a fork in the road provision as classically conceived either. Rather, the TTIP Proposal makes explicit the duty of the tribunal to "dismiss a claim by a claimant who has submitted a claim to the Tribunal or to any other domestic and international court or tribunal concerning the same treatment" (Article 14 (2)). This is in fact a strong and sweeping articulation of the fork in the road notion. The tribunal does not just have discretion to stay proceedings before another forum, but rather it has a duty to dismiss a claim that has been submitted to the concerned tribunal or indeed any other domestic or international court or tribunal. Further still, Article 14 (3) (a) (ii) of the TTIP Proposal requires that the claimant provide "evidence that [...] it has withdrawn any such claim or proceeding" and that "evidence shall contain, as applicable, proof that a final award, judgment or decision has been made or proof of the withdrawal of any such claim or proceeding".

The doctrine of election has also recently been applied in a creative way by an ICSID tribunal; with the latter also indicating that provision for this doctrine can find application as regards two international proceedings. Article 26 of the ICSID Convention is a good example and provides that "[c]onsent of the parties to arbitration under this Convention shall, unless otherwise stated, be deemed consent to such arbitration to the exclusion of any other remedy". In the recent Decision on Jurisdiction in Ampal-American $v$. Egypt,$^{52}$ the Tribunal found that an abuse of process had crystallized by virtue of the Claimant pursuing a claim before the ICSID Tribunal and the Permanent Court of Arbitration. In paragraph 337 of the Decision, the Tribunal quotes Article 26 of the ICSID Convention and goes on to reproduce a leading commentary on the ICSID Convention ${ }^{53}$ to indicate that

52 Ampal-American Israel Corp. v. Egypt, ICSID Case No. ARB/12/11, Decision on Jurisdiction of 1 February 2016.

53 C. Schreuer et al., The ICSID Convention: A Commentary (2009). 
consent to ICSID arbitration implies exclusive pursuit of a claim through ICSID (with respect to both international and national proceedings). In the following paragraph the Tribunal says:

Such an election would secure to Ampal in the present arbitration the advantages of the ICSID Convention, upon which it places special reliance, whilst removing the abuse constituted by the double pursuit of the same claim. ${ }^{54}$

The Tribunal subsequently offered the Claimant in that case the option to "[...] elect to pursue [a] portion of the claim in the present proceedings alone by 11 March 2016, or make its choice known at that time".55 The Tribunal then went on to stipulate that it would reconsider whether there had been an abuse of process by double pursuit of the same claim after the Claimant had indicated its choice to the Tribunal..$^{56}$

In addition, Article 27 of the ICSID Convention provides:

No Contracting State shall give diplomatic protection, or bring an international claim, in respect of a dispute which one of its nationals and another Contracting State shall have consented to submit or shall have submitted to arbitration under this Convention, unless such other Contracting State shall have failed to abide by and comply with the award rendered in such dispute.

These treaty provisions and their interpretation by international tribunals demonstrate an evolution in conception and operation of the fork in the road, waiver and election clauses. Whilst the criteria for these clauses to come into effect were previously strictly applied, which had the potential to increase the risk of parallel and overlapping procedures, more recently there has been a trend towards mitigating this risk by including provisions in treaties that are better suited to consolidating, staying or declining jurisdiction.

\section{B. Trade Law}

Turning now to the trade field, issues related to parallel litigation mechanisms can arise between free trade agreements and the WTO as well as be-

54 Ibid., para. 338.

55 Ibid., para. 339.

56 Ibid. 
tween two free trade agreements. ${ }^{57}$ The fact that many free trade agreements are making provision for autonomous dispute settlement mechanisms, leaves open the possibility for overlapping jurisdictions and conflicting judgments. However, the existence of parallel adjudication mechanisms is increasingly being dealt with through choice of forum clauses. Under NAFTA, for example, to deal with mitigating the risks of overlapping jurisdiction its Article 2005 allows applicant parties to choose whether to bring their claims before NAFTA or GATT dispute-settlement mechanisms, but also provides:

6. Once dispute settlement procedures have been initiated under Article 2007 or dispute settlement proceedings have been initiated under the GATT, the forum selected shall be used to the exclusion of the other, unless a Party makes a request pursuant to paragraph 3 or 4 .

The operation of Article 2005 is evident in the case-law of the WTO Dispute Settlement Body. The Appellate Body's decision in the Mexico-Soft Drinks case reveals the difficulties linked to jurisdictional overlaps as well as possible solutions to these challenges. ${ }^{58}$ In Casu, the question was to determine whether a WTO panel could decline to exercise jurisdiction over a particular dispute in favour of a NAFTA Chapter 20 panel, without diminishing the rights of the complaining WTO Member under the Dispute Settlement Understanding (DSU) and other covered agreements. The legitimacy of that question was heightened by the pronouncement of the Appellate Body in Mexico-Corn Syrup, where it had stated that "panels are required to address issues that are put before them by the parties to a dispute". 59 This cast doubt on the freedom of WTO panels to decline jurisdiction, despite their inherent power to determine whether a particular matter is within their jurisdiction. ${ }^{60}$

57 See for example L. Boisson de Chazournes, Interactions between Regional and Universal Organizations: A Legal Perspective (2016), 113-141.

58 Mexico - Tax Measures on Soft Drinks and other Beverages, Appellate Body Report, WT/DS308/AB/R (adopted 24 March 2006) [Mexico-Soft Drinks, Appellate Body Report].

59 Mexico-Anti-Dumping Investigation of High Fructose Corn Syrup (HFCS) from the United States, Appellate Body Report, WT/DS132/AB/RW (adopted 22 October 2001).

60 For a general discussion of inherent powers at the WTO, see I. Van Damme, Inherent Powers of and for the WTO Appellate Body, 55 (Ctr. for Trade \& Econ. Integration) Graduate Inst. of Int'l \& Dev. Studies - Working Paper (2008). 
The panel in Mexico-Soft Drinks considered it had no discretion to decide whether or not to exercise its jurisdiction in a case properly before it. ${ }^{61} \mathrm{Re}$ ferring to Article 11 of the DSU and to the ruling of the Appellate Body in Australia-Salmon, ${ }^{62}$ the Panel observed that "[...] the aim of the WTO dispute settlement system is to resolve the matter at issue in particular cases and to secure a positive solution to disputes" 63 and that a panel is required "[...] to address the claims on which a finding is necessary to enable the DSB to make sufficiently precise recommendations or rulings to the parties" ${ }^{64}$ It concluded that a WTO panel does not have full discretion as to whether it may exercise its jurisdiction. ${ }^{65}$

On appeal, Mexico contended that the Panel erred in rejecting Mexico's request that the Panel decline to exercise jurisdiction. ${ }^{66}$ According to Mexico, a panel had the power:

[...] to refrain from exercising substantive jurisdiction in circumstances where the underlying or predominant elements of a dispute derive from rules of international law under which claims cannot be judicially enforced in the WTO, such as the NAFTA provisions or when one of the disputing parties refuses to take the matter to the appropriate forum. ${ }^{67}$

The Appellate Body decided not to follow Mexico's assertions and rather declared that:

[...] panels have the right to determine whether they have jurisdiction in a given case, as well as to determine the scope of their jurisdiction. In this regard, the Appellate Body has previously stated that it is a widely accepted rule that an international tribunal is entitled to consider the issue of its own jurisdiction on its own initiative, and to satisfy itself that it has jurisdiction in any case that comes before it [...]. [I]t does not necessarily follow, however, from the existence of these inherent adjudicative powers that, once jurisdiction has been validly estab-

61 Mexico-Tax Measures on Soft Drinks and Other Beverages, Panel Report, 7.18, WT/DS308/R (adopted 7 October 2005) [Mexico-Soft Drinks, Panel Report].

62 Australia-Measures Affecting Importation of Salmon, Appellate Body Report 223, WT/DS18/AB/R (20 October 1998).

63 Mexico-Soft Drinks, Panel Report, supra note 61, para 7.8.

64 Ibid.

65 Ibid.

66 Mexico-Soft Drinks, Appellate Body Report, supra note 58 (quoting Mexico's Appellant's Submission).

67 Ibid. (internal quotations omitted). 
lished, WTO panels would have the authority to decline to rule on the entirety of the claims that are before them in a dispute. ${ }^{68}$

Although it upheld the finding of the Panel, the Appellate Body was careful to make an interesting qualification. Noting that it had expressed:

[...] no view as to whether there may be other circumstances in which legal impediments could exist that would preclude a panel from ruling on the merits of the claims that are before it. In the present case, Mexico argues that the United States' claims under Article III of the GATT 1994 are inextricably linked to a broader dispute, and that only a NAFTA panel could resolve the dispute as a whole. Nevertheless, Mexico does not take issue with the Panel's finding that neither the subject matter nor the respective positions of the parties are identical in the dispute under the NAFTA [...] and the dispute before us. Mexico also stated that it could not identify a legal basis that would allow it to raise, in a WTO dispute settlement proceeding, the market access claims it is pursuing under the NAFTA. It is furthermore undisputed that no NAFTA panel as yet has decided the broader dispute to which Mexico has alluded. Finally, we note that Mexico has expressly stated that the socalled exclusion clause of Article 2005.6 of the NAFTA had not been exercised. We do not express any view on whether a legal impediment to the exercise of a panel's jurisdiction would exist in the event that features such as those mentioned above were present. In any event, we see no legal impediments applicable in this case. ${ }^{69}$

The Appellate Body makes it clear here that, in some circumstances, a panel may decline to 'act at all' if another dispute settlement mechanism is more suitable to entertain jurisdiction. A panel may have to decline jurisdiction if there is a so-called 'legal impediment' to its hearing a case. Nonetheless, by contrast to the Arbitral Tribunal in the Mox Plant case, which will be considered later, the Appellate Body does not refer to 'soft' considerations of comity but rather to 'legal impediments' as competitionregulating means. Among these legal impediments, there is the possibility of invoking a fork in the road provision..$^{70}$ Interestingly, states parties to re-

68 Ibid., paras. 45-46 (internal citations and quotations omitted).

69 Mexico-Soft Drinks, Appellate Body Report, supra note 58, para. 54 (emphasis added) (internal citations omitted).

70 However, in the Mexico-Soft Drinks case, Mexico did not exercise the exclusion clause of Article 2005.6 NAFTA. See Mexico-Soft Drinks, Appellate Body Report, supra note 58 , footnote 110 of para. 54 . 
gional free trade agreements have not shown much appetite for activating them.

Under the EU-South Korea FTA, there are several features which appear to aim at the prevention of conflicting jurisprudence and/or parallel proceedings through an elaborate fork in the road provision. Among others, it should be noted that the Agreement leaves the choice of forum to the Parties, although Article 14.19(1) cautions that parties cannot litigate the same measure on the merits in two fora. Indeed, under Article 14.19(2), a Party "may not institute a dispute settlement proceeding regarding the same measure in the other forum until the first proceeding has been concluded". Further still, Article 14.19(2) provides that "a Party shall not seek redress of an obligation which is identical under this Agreement and under the WTO Agreement in the two forums" and that "once a dispute settlement proceeding has been initiated, the Party shall not bring a claim seeking redress of the identical obligation under the other Agreement to the other forum, unless the forum selected fails for procedural or jurisdictional reasons to make findings on the claim seeking redress of that obligation". These are indeed novel provisions which can be looked at as new types of fork in the road provisions. They intend to set constraints in the choice and type of proceedings that can be instituted.

As is evident, the fork in the road clause has found application in both the treaty and judicial practice of international trade law. It has been given various facets, which aim at restraining the possibility of parallel proceedings.

\section{Comity: Paving Its Way}

In dealing with principles and rules capable of coordinating parallel proceedings and avoiding jurisdictional overlaps or conflicting decisions, international courts and tribunals have also turned their attention to the principle of compétence de la compétence. ${ }^{71}$ In deciding upon their compétence de la compétence, tribunals may have recourse to considerations of comity, ${ }^{72}$ which may be defined as follows:

71 L. Boisson de Chazournes, The Principle of Competence de la Competence in International Adjudication and its Role in an Era of Multiplication of Courts and Tribunals, in M. Arasanjani et al. (eds.), Looking to the Future: Essays in Honor of W. Michael Reisman (2010), 1027-1064.

72 See Y. Shany, The Competing Jurisdiction of International Courts and Tribunals (2003), 260. 
A court or tribunal exercising discretionary jurisdiction [...] might be justified in deciding to defer jurisdiction in favour of another judicial body, which is better situated to address the particular dispute at hand and to take into consideration the various rights and interests of the parties before it. ${ }^{73}$

At the international level, comity is not a strict norm regulating jurisdictional overlaps between international courts and tribunals. It is rather a 'consideration' that may be taken into account in the exercise by an international court or tribunal of its compétence de la compétence and not the determining factor by which a court or a tribunal will decide its competence to act at all. This perception of comity is evident in the Order of the Arbitral Tribunal constituted under Annex VII of the Convention on the Law of the Sea in the Mox Plant case. Here, the Tribunal, dealing with its compétence de la compétence, stated:

In the circumstances, and bearing in mind considerations of mutual respect and comity which should prevail between judicial institutions both of which may be called upon to determine rights and obligations as between two States, the Tribunal considers that it would be inappropriate for it to proceed further with hearing the Parties on the merits of the dispute in the absence of a resolution of the problems referred to. Moreover, a procedure that might result in two conflicting decisions on the same issue would not be helpful to the resolution of the dispute between the Parties. ${ }^{74}$

A similar conception of comity was argued before an investment tribunal in the Eurêko $v$. The Slovak Republic case. ${ }^{75}$ Here, it was contended that there was a risk of conflicting decisions between the arbitral tribunal and the EU Commission and European Court of Justice due to the similarity of issues with a complaint filed by the investor regarding an alleged infringement of the EC Treaty. While the Tribunal decided to find jurisdiction, it did not deny the possible application of the comity principle in cases of procedural unfairness or inefficiency:

The Tribunal has considered whether it would be appropriate to suspend these arbitration proceedings until the EU Commission and/or

73 Ibid., 261-262.

74 The MOX Plant Case (Ireland v. United Kingdom), PCA UNCLOS Annex VII arbitration, Order No. 3 Suspension of 24 June 2003, para. 28.

75 Eurêko v. The Slovak Republic, PCA Case No. 2008-13 UNCITRAL, Award on Jurisdiction, Admissibility and Suspension of 26 October 2010, paras. 286-292. 
the ECJ have come to a decision on the EU law aspects of the infringement case. While the Tribunal wishes to organise its proceedings with full regard for considerations of mutual respect and comity as regards other courts and institutions, it does not consider that the questions in issue in the infringement case are so far coextensive with the claims in the present case that it is appropriate to suspend its proceedings now. Should it become evident at a later stage that the relationship between the two sets of proceedings is so close as to be a cause of procedural unfairness or serious inefficiency, the Tribunal will reconsider the question of suspension. ${ }^{76}$

Indeed, it seems that the Eurêko tribunal referred to considerations of the sound administration of justice, particularly regarding equality of arms, which could justify a stay of proceedings on the basis of comity. It even stated that it wanted to organize the proceedings "with full regard for considerations of mutual respect and comity".77 This case constitutes another interesting example of the potential for comity in allowing a court or a tribunal to order a stay of proceedings.

As such, comity is another concept which has the potential to be used to coordinate proceedings, and may be particularly useful in a changing dispute settlement environment in which judicial actors are increasingly aware of other judicial fora.

\section{Other Attempts to Order Coexisting Jurisdiction in the Trade and Investment Fields}

Other attempts to order coexisting jurisdiction are apparent in recent treaties as well. In this context, certain trends are evident across a variety of international instruments and in the case law of international tribunals. As such, a multitude of alternative means for ordering jurisdiction can be detected, most of which import or derive from the tools we have been speaking of. It is important to highlight that the lion's share of these developments can be seen in trade and investment agreements.

In the context of its investment provisions, CETA also mitigates the risk of overlapping jurisdictions by demarcating the scope of disputes falling under its dispute settlement mechanism. Article 8.18 of CETA requires a

76 Ibid., para 292.

77 Ibid. 
tribunal to dismiss claims that fall outside the jurisdiction set up by the CETA provisions:

Without prejudice to the rights and obligations of the Parties under Chapter Twenty- Nine (Dispute Settlement), an investor of a Party may submit to the Tribunal constituted under this Section a claim that the other Party has breached an obligation under: Section C, with respect to the expansion, conduct, operation, management, maintenance, use, enjoyment and sale or disposal of its covered investment; or Section D: where the investor claims to have suffered loss or damage as a result of the alleged breach. Claims under subparagraph $1(\mathrm{a})$ with respect to the expansion of a covered investment may be submitted only to the extent the measure relates to the existing business operations of a covered investment and the investor has, as a result, incurred loss or damage with respect to the covered investment. [...]

A Tribunal constituted under this Section shall not decide claims that fall outside of the scope of this Article.

The TPP also addresses the possibility of overlapping jurisdiction, this time at the very outset of the treaty. Article 1.2 (1) envisages the TPP's coexistence with other IIAs in the region that might be applicable:

Recognizing the Parties' intention for this Agreement to coexist with their existing international agreement, each Party affirms, [...] (b) in relation to existing international agreements to which that party and at least one other Party are party, its existing rights and obligations with respect to such other Party or Parties, as the case may be.

Article 1.2 (2) of the TPP goes on to explain that where there is an inconsistency between the provisions of the TPP and a pre-existing agreement, the concerned parties should consult with one another to find a mutually satisfactory solution. This is without prejudice to dispute settlement under the TPP. In a footnote, the TPP records that the Parties to the treaty have agreed:

$[\ldots]$ that the fact that an agreement provides more favourable treatment of goods, services, investments or persons than that provided for under this Agreement does not mean that there is an inconsistency $[\ldots]$.

The actual risks that may arise as a result of overlapping jurisdictions are to some extent mitigated through the use of time limits for bringing treaty claims. This is of course a different approach to that seen in CETA but nevertheless purports to achieve a similar aim and serves as a response to the 
realization that it exists in a multi-jurisdictional world. Article 9.21(1) of the TPP provides for the Conditions and Limitations on Consent of Each Party:

1. No claim shall be submitted to arbitration under this Section if more than three years and six months have elapsed from the date on which the claimant first acquired, or should have first acquired, knowledge of the breach alleged under Article 9.19.1 [...]

2. No claim shall be submitted to arbitration under this Section unless: (a) the claimant consents in writing to arbitration in accordance with the procedures set out in this Agreement; and the notice of arbitration is accompanied:

(i) for claims submitted to arbitration under Article 9.19.1(a) (Submission of a Claim to Arbitration), by the claimant's written waiver; and

(ii) for claims submitted to arbitration under Article 9.19.1(b) (Submission of a Claim to Arbitration), by the claimant's and the enterprise's written waivers, of any right to initiate or continue before any court or administrative tribunal under the law of a Party, or any other dispute settlement procedures, any proceeding with respect to any measure alleged to constitute a breach referred to in Article 9.19 (Submission of a Claim to Arbitration).

Under the most recent EU proposal for TTIP, taking a different approach again, a tribunal is required to identify and decline jurisdiction in the circumstances of a frivolous claim. This provision can also be seen as a manifestation of the good faith principle. This possibility may be seen as a means for preventing parallel or overlapping proceedings that may be initiated. As such, Article 15 on Anti-circumvention, which is concerned with situations where an investor acquires an investment in order to commence litigation, provides:

For greater certainty, the Tribunal shall decline jurisdiction where the dispute had arisen, or was foreseeable on the basis of a high degree of probability, at the time when the claimant acquired ownership or control of the investment subject to the dispute and the Tribunal determines, on the basis of the facts of the case, that the claimant has acquired ownership or control of the investment for the main purpose of submitting the claim under this Section. The possibility to decline jurisdiction in such circumstances is without prejudice to other jurisdictional objections which could be entertained by the Tribunal.

Recourse to the principle of good faith is also evident in the practice of investment dispute settlement. In several cases, it is possible to observe arbi- 
tration panels referring to this well-established principle of international law with a view to preventing abuse of process. As early as 1983 , the Tribunal in Amco Asia Corporation et al. v. Indonesia confirmed the centrality of good faith in interpreting conventions to arbitrate. ${ }^{78}$ However, more recently tribunals have considered the application of the principle in the broader context of international public order. For example, in Phoenix Action Ltd v. Czech Republic ${ }^{79}$ the Tribunal was concerned "[...] with the international principle of good faith as applied to the international arbitration mechanism of ICSID [...] to prevent an abuse of the system of international investment protection under the ICSID Convention, in ensuring that only investments that are made in compliance with the international principle of good faith and do not attempt to misuse the system are protected". ${ }^{80}$ Echoing these sentiments on protecting the investment treaty system from abuses of process, the ICSID tribunal in Transglobal Green Energy LLC and Transglobal Green Panama S.A. v. Republic of Panama upheld Panama's objection to jurisdiction in that case "[...] on the ground of abuse by Claimants of the investment treaty system by attempting to create artificial international jurisdiction over a pre-existing domestic dispute". 81

Overall, these provisions admit the contemporary reality of the coexistence of WTO, RTA, FTA and investment dispute settlement procedures. One can commend the various attempts at an organized coexistence in this respect. As has become evident from the emergent trends, different techniques have been embraced through treaties and responsibility is placed on courts and tribunals as well as parties to disputes in achieving this organized coexistence.

78 Amco Asia Corporation et al. v. Indonesia, ICSID Case No. ARB/81/1, Decision on Jurisdiction of 25 September 1983. The Tribunal stated: "Moreover - and this is again a general principle of law - any convention, including conventions to arbitrate, should be construed in good faith, that is to say by taking into account the consequences of their commitments the parties may be considered as having reasonably and legitimately envisaged", para. 14 (emphasis in original).

79 Phoenix Action Ltd v. Czech Republic, ICSID Case No. ARB/06/5, Award of 15 April 2009.

80 Ibid., para. 113 (emphasis in original).

81 Transglobal Green Energy LLC and Transglobal Green Panama S.A. v. Republic of Panama, ICSID Case No. ARB/13/28, Award of 2 June 2016, para. 118. 


\section{Conclusion}

In the light of a multiplication of international fora for the settlement of disputes, the likelihood of parallel proceedings and conflicting decisions has increased. This contemporary reality in the international legal order is one that domestic and regional legal systems have faced for some time. There exist well-developed procedural tools for coordinating jurisdiction in the private international law regimes of these domestic and regional systems.

While the international judiciary and law-makers have taken cognizance of these tools, they have also shied away from importing them "lock, stock and barrel", 82 preferring instead to adapt them for their own purposes and taking into account the specificities of the international judicial scene.

In this context, courts and tribunals have in recent years showed that they are aware of their role as actors of judicial change, and realize that they operate in a wider system of international dispute settlement. In addition, states have inserted various refined procedural tools in their recently negotiated treaties to prevent the undesirable consequences that arise from uncoordinated dispute settlement proceedings. This would suggest that their overriding concern is for securing the rule of law, rather than undermining it by introducing the risk of conflicting judgments, wasted resources and uncertainty. As such, the seeds have been sown for a more ordered co-existence. This also reveals a new dimension in multilateral efforts. Procedural rules play an increasingly significant role in the search for a more systemic approach to international dispute settlement.

82 To use the words of Lord McNair in his Separate Opinion to the Advisory Opinion of the ICJ in International Status of South-West Africa, ICJ Rep. 1950, 128, 148. 
